\title{
The Impact Analysis of Seismic Performance of Setting Up the Core Column Strengthening Measures on Short Column Structure
}

\author{
Rirong FU ${ }^{1,}$ a , Kangning Liu ${ }^{2, b}$,Guangchuang Men ${ }^{1, \mathrm{c}}$, Li Hui ${ }^{1, \mathrm{~d}}$ \\ ${ }^{1}$ Shandong Jianzhu University,School of Civil Engineering, Jinan, China, 250101 \\ ${ }^{2}$ Shandong Lianchuang Architectural Design Co., Ltd. Jinan, China, 250101 \\ afurirong@163.com, b435713581@qq.com, c43734450@qq.com, ${ }^{\mathrm{d}} 582616441 @ q q . c o m$
}

\begin{abstract}
Keywords:core short column, tall reinforced concrete structure with more short columns,seismic performance,pushover analysis

Abstract. In a complex high-rise concrete structure design, concrete frame column may become short column.The stiffness of reinforced concrete short column is larger than ordinary concrete column. Under earthquake excitation,the short column shares more earthquake action, and its deformation capacity and energy dissipation ability is poor,at last the short column presents shear failure.In this paper, we analyze the seismic performance of high-rise frame-shear wall structure and high-rise frame-shear wall structure with core reinforced columns when disastrous earthquake occurs in the region.At last, we draw that the core column has large promotion compared with the original structure.And meet the "No Collapsing with Strong Earthquake" fortification requirements and"Strong Column and Weak Beam","Strong Shear Capacity and Weak Bending Capacity"seismic design philosophy.
\end{abstract}

\section{Introduction}

In order to adapt to the rapid development of social and economic, more and more complex high-rise building structures emerge as the times require.Complex high-rise concrete structure design may be affected or restricted by building features, height, load, high beam and so on.Concrete frame column may become short column. The deformation ability and energy dissipation ability of reinforced concrete short column are poor, often appear the brittle shear failure ${ }^{[1]}$ in the earthquake. When structure contains short columns especially more short columns, some seismic measures should be taken to meet the requirements of the seismic fortification ductility.

At this stage,little study on seismic performance of over-all structure containing reinforced concrete short columns has been done.At home and abroad much study lay more emphasis on single reinforced concrete short column component test and theoretical analysis, and measures are put forward to improve the ductility of reinforced concrete short column.

For the complex structure and structure with potentially weak parts, elastic seismic theory fails to accurately grasp the inelastic phase's actual reaction of the structure under seismic action.We can not guarantee the safety of the structure under the action of middle seismic or rare earthquake.So the structure elastoplastic analysis is necessary.

This paper is on the background of a practical engineering of high-rise frame-shear structure with more short columns, the pushover analyses the seismic performance of setting up the core column strengthening measures on short column structure before and after,under the region's severe earthquake, and study on the impact of seismic performance of the integral structure after taking on the core column strengthening measures .

\section{Project Profile}

The basic intensity of examples in this engineering area is 7 degrees $(0.15 \mathrm{~g})$, earthquakes are grouped into the third group, site classification is class II, $\mathrm{Tg}=0.45 \mathrm{~S}$. Basic wind pressure takes 0.45 $\mathrm{KN} / \mathrm{m}^{2}$, the main building total height is $98.300 \mathrm{~m}$. The first and second floor underground are garage,and there are 28 floors aboveground.The first and second floor are used for business,and the floor height are $3.800 \mathrm{~m}$ and $3.600 \mathrm{~m}$. Floors from 3th to 28th are used for business office and the floor 
height is $3.300 \mathrm{~m}$. The main building structure is the frame - shear wall structure, regarding that the column spacing of the structure is large, height of column section and beam section is relatively large, so more short columns which shear span ratio is less than 2 are formed.It is a high-level framework shear wall structure containing a higher proportion of short column. The standard floor structure floor plan is shown in Fig.1:

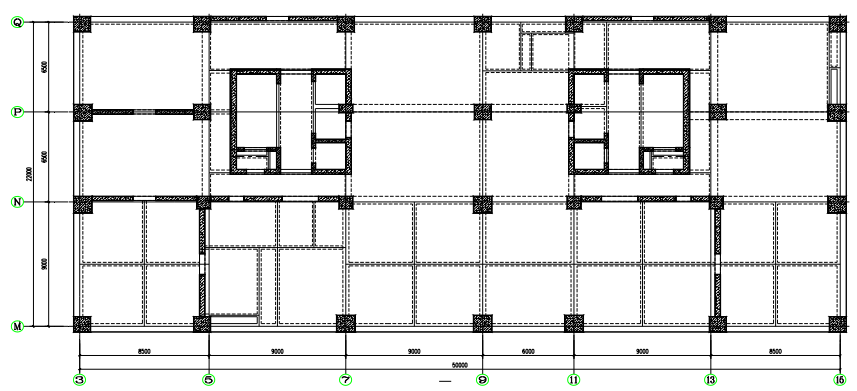

Fig.1.Standard Floor Structure Floor Plan

\section{Seismic Performance of Structure According to the Conventional Design}

The high-rise frame-shear wall structure with a higher proportion of short column deigns according to the routine method.Concrete short columns does not take special strengthening measures. Use the general finite element analysis software Midas gen and the mode (the main formation) loading mode.Each node force is connected with mode displacement, vibration angular frequency square and the quality assigned to the node.Do static elastoplastic analysis of structures, observe its weak positions and seismic performance.

After using Midas gen pushover analysis,the ability- demand spectrum curve and the plastic hinge distribution of the structure are as shown in Fig.2, Fig.3.

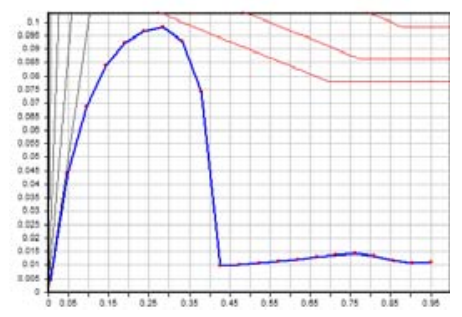

(a) The rare earthquake ability-demand spectrum curve in the $\mathrm{x}$ direction

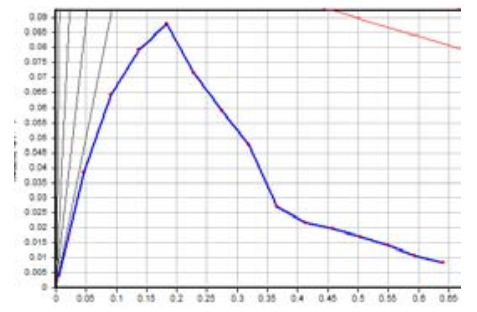

(b)The rare earthquake ability-demand spectrum curve in the of y direction

Fig.2.The Ability- Demand Spectrum Curve of the Structure

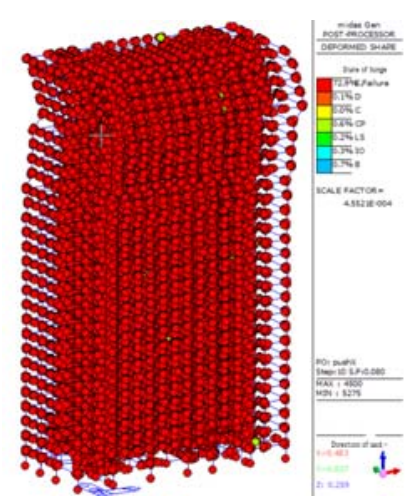

(c)Plastic hinge distribution of the structure in the $\mathrm{x}$ direction

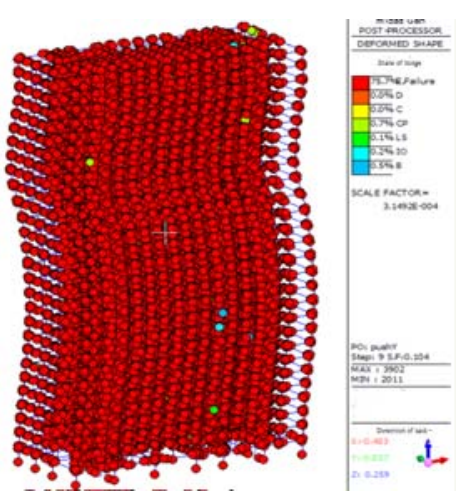

(d)Plastic hinge distribution of the structure in the y direction

Fig.3.The Plastic Hinge Distribution of the Vertical Unit under Yield State 
As is shown in Fig.3,under rare earthquake of 7 degrees( $0.15 \mathrm{~g})$,and when loading in the $\mathrm{x}$ and $\mathrm{y}$ direction,plastic hinge occurs in almost all of the frame column. The shear hinge accounted for $71.4 \%$ and $78.2 \%$ respectively.Bending moment hinge accounted for $26.1 \%$ and $14.2 \%$.Axial force hinge accounted for $2.5 \%$ and $7.6 \%$.Frame column shear failure factors in the plastic hinge components account for larger proportion,which violated the "Strong Column and Weak Beam","Strong Shear Capacity and Weak Bending Capacity" seismic design philosophy.Almost all floors of the building appear brittle failure, and short column strengthening measures of the structure of the framework is necessary.

\section{The Seismic Performance of the Structure After Setting Up the Core Column Strengthening Measures}

Strengthen the short column component of original structure by taking core column measures (as shown in Fig.4.a).Use Xtract to build core column model and then obtain component yield curve (as shown in Fig.4.b, c).According to the drawing of the yield curve define corresponding yield surface in software .

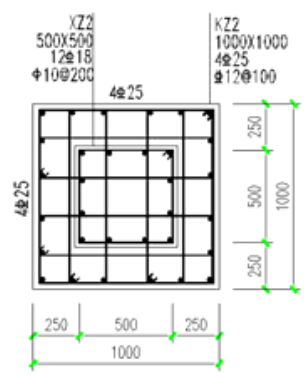

a.Core short column reinforcement drawing

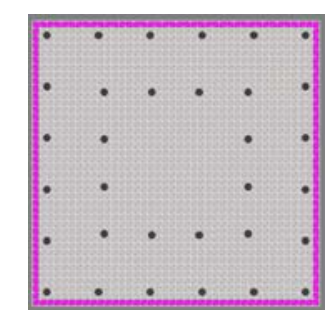

b.Build core column component model in Xtract

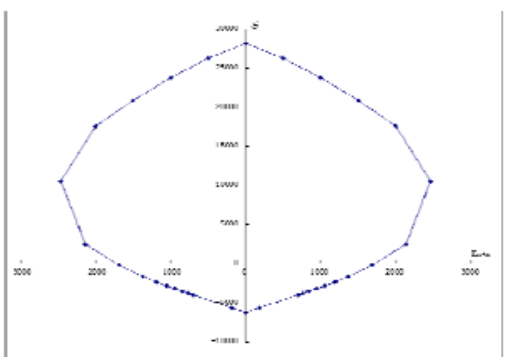

c. The yield surface curve of the core column component

Fig.4.Core Column Component Schematic Cross Section

After using Midas gen pushover analysis, the ability - demand spectrum curve and the plastic hinge distribution of the structure are as shown in Fig.5.

As is shown in Fig.5,under rare earthquake,plastic hinges of structure appear first on the coupling beam of shear wall and frame beam.With the increase of lateral displacement,plastic hinge of shear wall gradually appear.Load to the performance points, the plastic hinge does not appear in frame column.Frame column are in a state of not to yield.In line with the "Strong Column and Weak Beam","Strong Shear Capacity and Weak Bending Capacity" seismic design philosophy.

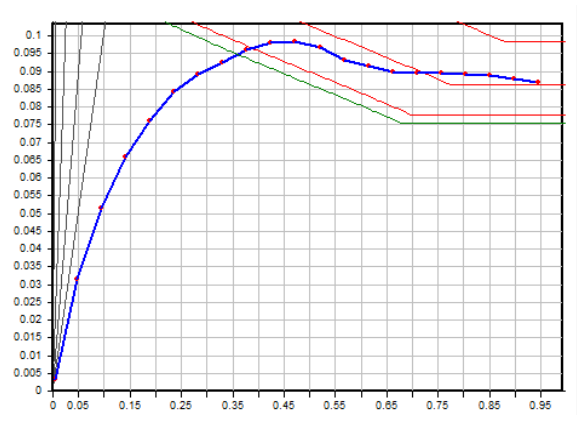

(a) The rare earthquake ability-demand spectrum curve in the $\mathrm{x}$ direction

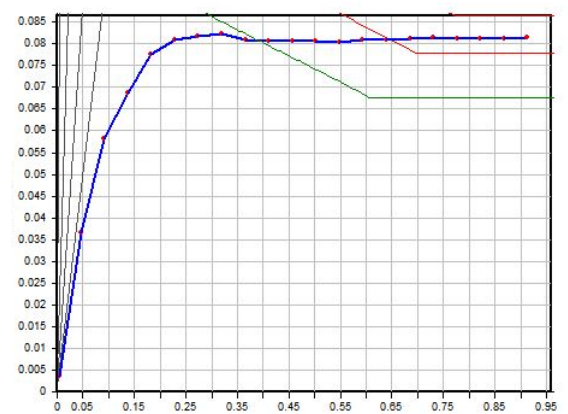

(b) The rare earthquake ability-demand spectrum curve in the of y direction 


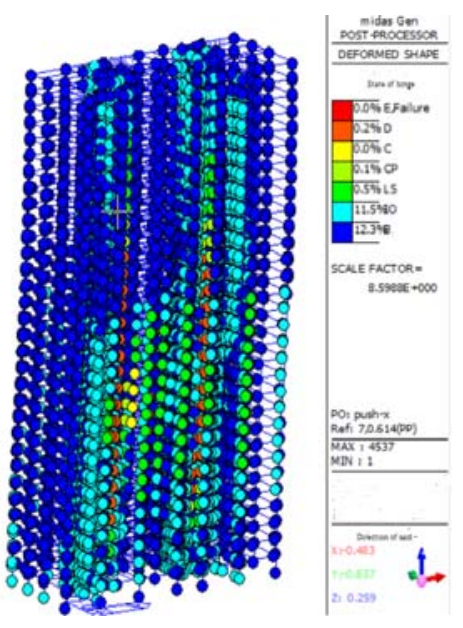

(c)performance point with plastic hinge distribution in $\mathrm{x}$ direction

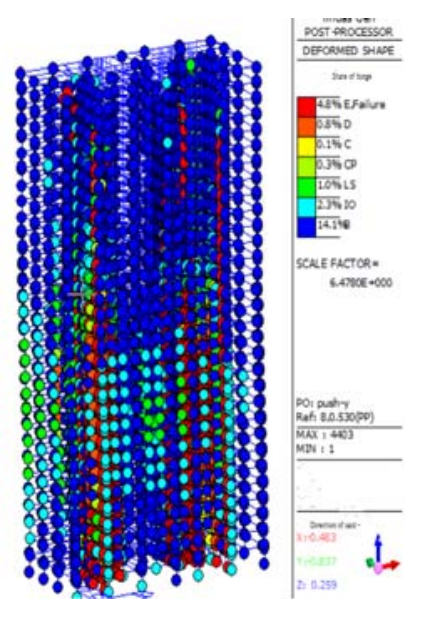

(d)performance point with plastic hinge distribution in y direction

Fig.5.Performance Point with Plastic Hinge Distribution of the Structure

\section{Conclusions}

This paper is on the background of high-rise frame shear structure practical engineering with more short columns,adopt core column reinforcing measures on the original structure and then proceed the pushover analysis. The results show that almost all of the plastic hinges of the reinforced concrete short columns of the original structure appear under region's rare earthquakes. The failure modes are most shear destruction.Structure ductility is poor,the structure can not meet the "No Collapsing with Strong Earthquake",seismic fortification requirements of multi pass line of defense and "Strong Column and Weak Beam"and"Strong Shear Capacity and Weak Bending Capacity" concept of seismic fortification.But structural seismic performance has larger promotion after taking core column measures.The structure has performance point under strong earthquake.Coupling beam structure damages in the first place.Then shear wall plastic hinges appear.Load to the performance points, the plastic hinge does not appear in frame columns.Frame columns are in a state of not to yield and meet the "No Collapsing with Strong Earthquake",seismic fortification requirements of multi pass line of defense and "Strong Column and Weak Beam"and"Strong Shear Capacity and Weak Bending Capacity" concept of seismic fortification. The core short column is a powerful measure to improve the seismic performance of short column structure.

\section{References}

[1] GB50011-2010.Code for Seismic Design of Buildings[S].Beijing:China Architecture Building Press,2010;61-63,58-60,35-42,

[2] Guochun Wu.Acta Geologica Sinica,2012,34(3)408. 414

[3] Xueyi Fu. Practical High-Rise Building Structure Design[M]-Beijing, China Architecture Building Press, 2011, 198. 199

[4] Liaoyuan Ye,Baishan Panjiang,Guoliang Bai.Journal of Building Structures.2000,21(2):37-51

[5] Somerville, P. G., Smith, M., Punyamurthula, S., and Sun, J. (1997), Development of Ground Motion Time Histories for Phase 2 of the FEMA/SAC Steel Project[R], Report No.SAC/BD-97/04, SAC Joint Venture, Sacramento, CA. 